https://jurnal.unigal.ac.id/index.php/edukasi

\title{
ANALISIS PERPUTARAN MODAL KERJA DAN CURRENT RATIO TERHADAP RETURN ON ASSET
}

\author{
Oleh: \\ Angga Gumilar \\ Sekolah Tinggi Ilmu Sosial dan Ilmu Pemerintahan Bina Putera Banjar, Indonesia \\ Email:gumilarangga@gmail.com \\ Sejarah Artikel: Diterima April 2019, Disetujui Mei 2019, Dipublikasikan Juni 2019
}

\begin{abstract}
ABSTRAK
Tujuan dari penelitian ini adalah untuk menganalisis perputaran modal kerja, Current Ratio, Return on Asset, dan besarnya pengaruh perputaran modal kerja dan Current Ratio terhadap Return on Asset PT Mayora Indah Tbk periode 2007-2016. Penelitian ini menggunakan pendekatan kuantitatif dengan jenis metodenya explanatory. Sumber data sekunder dengan teknik sampling analisis time series. Metode statistik analisis jalur (path analysis), serta dilakukan uji asumsi klasik. Hasil penelitian ini menemukan bahwa perputaran modal kerja, Current Ratio, dan Return on Asset PT Mayora Indah Tbk periode 2007-2019 cenderung fluktuatif. Pengaruh perputaran modal kerja dan Current Ratio terhadap Return on Asset sebesar 5\%, pengaruh perputaran modal kerja terhadap Return on Asset sebesar -0,08\%, dan pengaruh Current Ratio terhadap Return on Asset sebesar 5,04\%. Berdasarkan uji hipotesis, tidak terdapat pengaruh signifikan perputaran modal kerja, Current Ratio terhadap Return on Asset pada PT Mayora Indah Tbk periode 2007-2016 baik secara parsial ataupun secara simultan.
\end{abstract}

Kata Kunci: Modal Kerja, Current Ratio, Return on Asset

\section{PENDAHULUAN}

Mengukur kinerja keuangan perusahaan dapat dilakukan dengan cara menganalisis laporan keuangan perusahaan tersebut menggunakan rasio keuangan. Rasio-rasio tersebut antara lain rasio likuiditas, rasio solvabilitas, rasio aktivitas, dan rasio profitabilitas. Rasio profitabilitas menggambarkan kemampuan perusahaan dalam memperoleh keuntungan, semakin tinggi rasio ini maka semakin baik. Rasio yang populer mengenai hasil perolehan laba adalah Return on Asset. Return on Asset (ROA) digunakan untuk mengukur kemampuan perusahaan dalam menghasilkan keuntungan pada periode sebelumnya untuk kemudian diproyeksikan di masa yang akan datang. Apabila perusahaan ingin meningkatkan profitabilitasnya maka faktor yang dapat mempengaruhinya adalah perputaran modal kerja dan likuiditas.

Perputaran modal kerja merupakan salah satu rasio untuk mengukur atau menilai keefektifan modal kerja perusahaan selama periode tertentu. Rasio likuiditas yang diwakili oleh Current Ratio merupakan perbandingan antara aktiva lancar dan kewajiban lancar dan merupakan ukuran yang paling umum digunakan untuk mengetahui kesanggupan suatu perusahaan memenuhi kewajiban jangka pendeknya.

Pada tahun 2016 pertumbuhan industri food and beverage sebesar $8,4 \%$ di mana tingkat pertumbuhan ini di atas pertumbuhan ekonomi sebesar 5,02\%. Pertumbuhan ini hampir dua kali lipat dari pertumbuhan ekonomi nasional. Sektor industri food and beverage merupakan salah satu sektor usaha yang terus mengalami pertumbuhan. Seiring meningkatnya pertumbuhan jumlah penduduk di Indonesia, volume kebutuhan terhadap food and beverage pun terus meningkat. Kecenderungan masyarakat Indonesia untuk menikmati makanan ready to eat menyebabkan banyak bermunculan perusahaan-perusahaan baru di bidang food and beverage. Oleh karena itu, persaingan antar perusahaan pun semakin kuat. (Sumber: http://ekbis.sindonews.com) 
Berikut ini adalah data rata-rata Return on Asset (ROA) tahun 2016 perusahaan food and beverage yang terdaftar di Bursa Efek Indonesia (BEI).

Tabel 1:

Return On Asset (Roa) Perusahaan Food And Beverage Yang Terdaftar

Di Bursa Efek IndonesiaTahun 2016

\begin{tabular}{clc} 
NO & \multicolumn{1}{c}{ NAMA PERUSAHAAN } & RETURN ON ASSET (ROA) \\
\hline 1 & PT Multi Bintang Indonesia Tbk (MLBI) & $58,03 \%$ \\
2 & PT Delta Djakarta Tbk (DLTA) & $21,18 \%$ \\
3 & PT Ultrajaya Milk Industry Tbk (ULTJ) & $20,97 \%$ \\
4 & PT Cahaya Kalbar Tbk (CEKA) & $20,04 \%$ \\
5 & PT Tiga Pilar Sejahtera Food Tbk (AISA) & $13,85 \%$ \\
6 & PT Indofood Sukses Makmur Tbk (INDF) & $12,50 \%$ \\
7 & PT Mayora Indah Tbk (MYOR) & $10,75 \%$ \\
8 & PT Akasha Wira International Tbk (ADES) & $8,03 \%$ \\
9 & PT Sekar Laut Tbk (SKLT) & $4,43 \%$ \\
10 & PT Prasidha Aneka Niaga Tbk (PSDN) & $1,55 \%$ \\
\hline \multicolumn{3}{c}{ JUMLAH } \\
\multicolumn{2}{c}{ RATA-RATA } & $171,33 \%$ \\
& & $17,13 \%$
\end{tabular}

Sumber: ww.idx.co.id (data diolah kembali)

Rrata-rata Return on Asset (ROA) dari perusahaan sejenis adalah $17,13 \%$. Salah satu perusahaan yang nilai ROA-nya berada di bawah rata-rata adalah PT Mayora Indah Tbk. Return on Asset (ROA) PT Mayora Indah Tbk pada tahun 2016 yaitu sebesar 10,75\%.

Salah satu cara untuk mencapai tujuan perusahaan, diperlukan manajemen dengan tingkat efektivitas yang tinggi. Pengukuran tingkat efektivitas manajemen yang ditunjukkan oleh laba yang dihasilkan dari penjualan dan dari pendapatan investasi, dapat dilakukan dengan mengetahui seberapa besar rasio profitabilitas yang dimiliki perusahaan.

Retun on Asset (ROA) pada PT Mayora Indah Tbk tahun 2010 sebesar $11,00 \%$ tahun 2011 mengalami penurunan $-3,67 \%$ menjadi 7,33\% tahun 2012 Retun on Asset (ROA) PT Mayora Indah Tbk naik 1,62\% menjadi 8,95\% dan pada tahun 2013 juga mengalami kenaikan 1,44\% menjadi 10,39\% namun pada tahun 2014 mengalami penurunan yang sangat signifikan yaitu $-6,60 \%$ menjadi $3,79 \%$ di tahun 2015 mengalami kenaikan yang sangat signifikan sebesar $7,38 \%$ menjadi $11,17 \%$ dan di tahun 2016 PT Mayora Indah Tbk mengalami penurunan sedikit hanya $-0,42 \%$ menjadi $10,75 \%$.

Berdasarkan fenomena permasalahan yang terjadi pada PT Mayora Indah Tbk di antaranya adalah Return on Asset (ROA) PT Mayora Indah Tbk yang berada di bawah ratarata dari perusahaan-perusahaan yang tergabung dalam industri food and beverage yang terdaftar di Bursa Efek Indonesia (BEI). Posisi PT Mayora Indah Tbk jika dianalisis berada di posisi keempat terakhir market share dari 10 perusahaan yang terdaftar di sektor food and beverage. Posisi ini dapat mengancam kedudukan nilai perusahaan dari kepercayaan para investor dan stakeholder lainnya. Kondisi Return on Asset (ROA) pertahun cenderung fluktuatif, menurunnya pertumbuhan Return on Asset (ROA) PT Mayora Indah Tbk khususnya pada tahun 2011 dan 2014, tentunya akan berdampak pada penurunan kinerja keuangan. Hal ini diduga karena perputaran modal kerja perusahaan yang cenderung lambat dan kondisi likuiditas perusahaan sehingga menyebabkan laba operasi cenderung menurun Penelitian ini ditujukan untuk menganalisis pengaruh perputaran modal kerja dan Current Ratio terhadap Return on Asset pada PT Mayora Indah Tbk periode 2007-2016.

\section{METODE PENELITIAN \\ Jenis Penelitian}

Penelitian ini menggunakan pendekatan kuantitatif metodenya Explanatory Research. Alasan pemilihan jenis penelitian eksplanatori 
ini untuk menguji hipotesis yang diajukan agar dapat menjelaskan pengaruh perputaran modal kerja dan Current Ratio sebagai variabel bebas terhadap Return on Asset (ROA) sebagai variabel terikat baik secara parsial maupun simultan yang ada dalam hipotesis tersebut.

\section{Operasionalisasi Variabel Penelitian}

Operasionalisasi variabel penelitian dimaksudkan untuk menjabarkan variabelvariabel yang timbul dalam suatu penelitian ke dalam indikator-indikator yang lebih terperinci. Variabel dalam penelitian ini disajikan pada tabel di bawah ini:

Tabel 2

Operasionalisasi Variabel

\begin{tabular}{|c|c|c|c|}
\hline Variabel & Dimensi & Indikator & Skala \\
\hline $\begin{array}{l}\text { Perputaran } \\
\text { Modal Kerja } \\
\text { (X1) } \\
\text { (Kasmir, } \\
\text { 2015) }\end{array}$ & $\begin{array}{l}\text { Perputaran Modal Kerja merupakan } \\
\text { salah satu rasio untuk mengukur atau } \\
\text { menilai keefektifannya modal kerja } \\
\text { perusahaan selama periode tertentu. } \\
\text { Untuk mengukur rasio ini, kita } \\
\text { membandingkan antara penjualan } \\
\text { dengan modal kerja atau dengan modal } \\
\text { kerja rata-rata. }\end{array}$ & $\frac{\text { Penjualan Bersih }}{\text { Modal kerja }}$ & Ratio \\
\hline $\begin{array}{l}\text { Current } \\
\text { Ratio (CR) } \\
\text { (X2) } \\
\text { (Kasmir, } \\
\text { 2015) }\end{array}$ & $\begin{array}{l}\text { Current Ratio yaitu rasio likuiditas } \\
\text { yang digunakan untuk mengukur } \\
\text { kemampuan perusahaan dalam } \\
\text { memenuhi kewajiban jangka pendek } \\
\text { yang akan segera jatuh tempo pada } \\
\text { saat ditagih secara keseluruhan. } \\
\text { Perhitungan dilakukan dengan cara } \\
\text { membandingkan antara total aktiva } \\
\text { lancar dengan total utang lancar. }\end{array}$ & $\frac{\text { Aktiva lancar }}{\text { Utang lancar }}$ & Ratio \\
\hline $\begin{array}{l}\text { Return on } \\
\text { Asset (ROA) } \\
\text { (Y) (Kasmir, } \\
\text { 2015) }\end{array}$ & $\begin{array}{l}\text { Rasio yang menunjukkan hasil atas } \\
\text { jumlah aktiva yang digunakan dalam } \\
\text { perusahaan. Untuk mencari rasio ini } \\
\text { dengan cara membandingkan antara } \\
\text { laba sesudah bunga dan pajak dengan } \\
\text { total aktiva }\end{array}$ & $\begin{array}{l}\text { Earning After Interest } \\
\text { and Tax } \\
\text { Total Aktiva }\end{array}$ & Ratio \\
\hline
\end{tabular}

\section{Teknik Pengumpulan Data}

Penelitian ini menggunakan data sekunder dengan teknik analisis time series. Peneliti melakukan penelitian di Pojok Bursa Efek Indonesia (BEI) Fakultas Ekonomi Universitas Siliwangi Tasikmalaya untuk memperoleh data laporan keuangan dan profil PT Mayora Indah Tbk.

\section{Teknik Analisis Data}

Penelitian ini teknik analisis datanya menggunakan uji asumsi klasik yaitu uji linearitas, normalitas, heteroskedastisitas, multikolinearitas, dan autokorelasi. Untuk mengetahui besarnya pengaruh antara variabel bebas dengan variabel terikat dilakukan dengan menggunakan analisis jalur (Path Analysis).

Berikut ini diagram jalur menurut (Somantri \& Muhidin, 2006): 


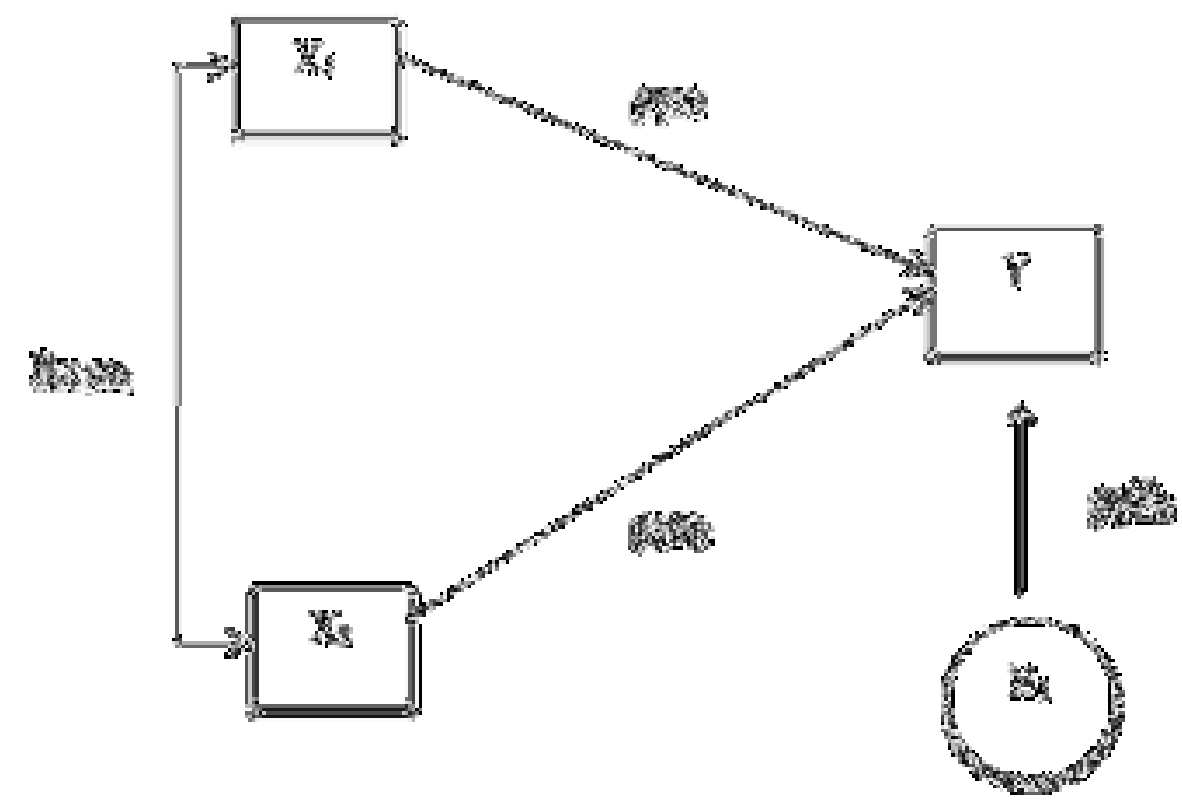

Gambar 1

Path Analysis

Keterangan:

$\mathrm{X}_{1}$

$\mathrm{X}_{2}$

$\mathrm{Y}$

$\mathrm{E}_{1} \quad:$ Faktor lain yang tidak diteliti

$\mathrm{Rx}_{1} \mathrm{X}_{2} \quad$ : Koefisien jalur variabel $\mathrm{X}_{1}$ dengan $\mathrm{X}_{2}$

$\rho \gamma \mathrm{x}_{1} \quad:$ Koefisien jalur variabel $\mathrm{X}_{1}$ terhadap $\mathrm{Y}$

$\rho \gamma x_{2} \quad:$ Koefisien jalur variabel $X_{2}$ terhadap $Y$

$\rho \mathrm{E}_{2} \quad:$ Koefisien jalur variabel $\mathrm{E}_{1}$ terhadap variabel $\mathrm{Y}$

Berdasarkan hipotesis konseptual yang diajukan, maka perumusan hipotesisnya adalah:

Ho $: \rho \gamma \mathrm{x}_{1}=0$

Ha $: \rho \gamma \mathrm{x}_{1} \neq$ di mana $1=1$ dan 2

Dengan kriteria penolakan Ho jika $\mathrm{F}_{\mathrm{o}}>\mathrm{F}_{\text {tabel }}$

Setelah melakukan pengujian hipotesis secara simultan (keseluruhan), maka untuk menguji perbedaan besarnya pengaruh masing-masing variabel eksogenus terhadap variabel endogenus.

Uji statistik di atas mengikuti distribusi t dengan derajat bebas $n-k-1$ dengan kriteria penolakan Ho jika $\mathrm{t}_{0}>\mathrm{t}_{\text {tabel }(\mathrm{n}-\mathrm{k}-1)}$

Keterangan:

$\mathrm{P}_{\gamma \mathrm{xi}}$

$=$ Koefisien jalur (besarnya pengaruh) variabel $\mathrm{Xi}$ terhadap variabel Y

$\mathrm{R}^{2} \mathrm{yx} \quad=$ Koefisien yang menyatakan determinasi total dari semua variabel $\mathrm{X}$ terhadap variabel $\mathrm{Y}\left(\rho_{\mathrm{yx} 1} \mathrm{r}_{\mathrm{yx} 1}+\right.$ $\left.\rho_{\mathrm{yx} 2} \mathrm{r}_{\mathrm{yx} 2}\right)$

$\mathrm{R} 2 \mathrm{yx}_{\mathrm{i}} \ldots\left(\mathrm{x}_{\mathrm{i}}\right) \ldots . . \mathrm{x}_{\mathrm{k}}=$ Koefisien yang menyatakan determinasi multiple antara Xi dengan X1,.....Xk tanpa Xi.

Mencari pengaruh dari satu variabel ke variabel lainnya, baik secara langsung maupun tidak langsung dapat disajikan melalui formula yang disajikan dalam Tabel 2 sebagai berikut: 
Tabel 3:

Formula untuk Mencari Pengaruh Langsung dan Tidak Langsung Antara Variabel Penelitian

\begin{tabular}{|c|c|c|c|}
\hline NO & Pengaruh Langsung & Pengaruh tidak Langsung & Total Pengaruh \\
\hline \multirow[t]{3}{*}{1} & Variabel $X_{1}$ & & $\mathrm{~A}$ \\
\hline & $\mathrm{Y} \leftarrow \mathrm{X}_{1} \rightarrow \mathrm{Y}:\left(\rho_{\mathrm{yx} 1}\right)^{2}=\mathrm{A}$ & $\begin{array}{l}\text { Melalui } X_{2} Y \leftarrow X_{1} \Omega X_{2} \rightarrow Y \\
\left(\rho_{y x 1}\right)\left(r_{1} x_{2}\right)\left(\rho y_{2}\right)=B\end{array}$ & B \\
\hline & Total pengaruh $\mathrm{X}_{1} \rightarrow \mathrm{Y}$ & - & $\mathrm{A}+\mathrm{B}$ \\
\hline \multirow[t]{5}{*}{2} & Variabel $\mathrm{X}_{2}$ & - & $\mathrm{C}$ \\
\hline & $\mathrm{Y} \leftarrow \mathrm{X}_{2} \rightarrow \mathrm{Y}:\left(\rho \mathrm{yx}_{2}\right)^{2}=\mathrm{C}$ & $\mathrm{X}_{2} \mathrm{Y} \leftarrow \mathrm{X}_{1} \Omega \mathrm{X}_{2} \rightarrow$ & $\mathrm{D}$ \\
\hline & & $\mathrm{Y}\left(\rho_{\mathrm{YX} 1}\right)\left(\mathrm{rx}_{1} \mathrm{x}_{2}\right)\left(\rho \mathrm{yx}_{2}\right)=\mathrm{D}$ & \\
\hline & Total pengaruh $\mathrm{X}_{2} \rightarrow \mathrm{Y}$ & - & $\mathrm{C}+\mathrm{D}$ \\
\hline & Total pengaruh $\mathrm{X}_{1}, \mathrm{X}_{2}$ & & $(\mathrm{~A}+\mathrm{B})+(\mathrm{C}+\mathrm{D})=\mathrm{E}$ \\
\hline
\end{tabular}

\section{HASIL PENELITIAN DAN PEMBAHASAN}

Untuk mengetahui pengaruh perputaran modal kerja dan Current Ratio terhadap Return on Asset, disajikan data sebagai berikut:

Tabel 4:

Perputaran Modal Kerja, Current Ratio Dan Return On Asset Pada PT Mayora Indah Tbk Periode 2007-2016

\begin{tabular}{cccc} 
Tahun & $\begin{array}{c}\text { Perputaran Modal Kerja } \\
\text { (dalam kali) }\end{array}$ & $\begin{array}{c}\text { Current Ratio } \\
\text { (dalam kali) }\end{array}$ & $\begin{array}{c}\text { Return on Asset (dalam } \\
\text { persentase) }\end{array}$ \\
\hline 2007 & 2,71 & 2,93 & 7,48 \\
2008 & 2,32 & 2,19 & 6,71 \\
2009 & 2,73 & 2,29 & 11,46 \\
2010 & 2,69 & 2,58 & 11,00 \\
2011 & 2,31 & 2,22 & 7,33 \\
2012 & 1,98 & 2,76 & 8,95 \\
2013 & 1,87 & 2,40 & 10,39 \\
2014 & 2,18 & 2,09 & 3,79 \\
2015 & 1,99 & 2,37 & 11,17 \\
2016 & 2,10 & 2,25 & 10,75
\end{tabular}

Sumber: Pojok Bursa Efek Indonesia, 2017

Berdasarkan tabel di atas dapat disimpulkan bahwa data cenderung fluktuatif. Perputaran modal kerja paling tinggi pada tahun 2009 yaitu sebesar 2,73 kali dan terendah tahun 2013 yaitu sebesar 1,87 kali. Current Ratio paling tinggi pada tahun 2007 sebesar 2,93 kali dan terendah pada tahun 2014 sebesar 2,09 kali. Return on Asset paling tinggi pada tahun 2009 yaitu sebesar 11,46\% dan terendah pada tahun 2014 yaitu sebesar 3,79\%. Pada tahun 2014 laba pada PT Mayora Indah Tbk cenderung menurun sehingga Return on Asset pada tahun 2014 turun secara signifikan.

\section{Uji Normalitas}

Berdasarkan hasil analisis data bahwa terjadi kurva berbentuk lonceng, terlihat titik-titik mengikuti dan mendekati garis diagonal dan masih menyebar di sekitar garis diagonal, titik-titik tidak 
membuat pola yang jelas, dan titik-titik menyebar di atas dan di bawah angka 0 pada sumbu $Y$, dan uji Kolmogrov-smirnov (k-s) dihasilkan nilai signifikansi $>0,05$ artinya data berdistribusi normal.

\section{Uji Heteroskedastisitas}

Berdasarkan hasil analisis data bahwa titik-titik tidak membuat pola yang jelas, dan titik-titik menyebar di atas dan di bawah angka 0 pada sumbu $Y$, nilai signifikansi variabel perputaran modal kerja dan Current Ratio $>0,05$ artinya data tersebut tidak terjadi heteroskedastisitas.

\section{Uji Multikolinearitas}

Berdasarkan hasil analisis data bahwa nilai tolerance variabel perputaran modal kerja dan Current Ratio $>0,10$ dan besaran Variance Inflation Factor (VIF) kurang dari 10 sehingga dapat disimpulkan tidak terjadi multikolinearitas.

\section{Uji Linearitas}

Berdasarkan hasil analisis data bahwa bahwa nilai $\mathrm{Z1}>0,05$ artinya data yang dihasilkan berdistribusi linear.

\section{Uji Autokorelasi}

Berdasarkan hasil analisis data bahwa nilai Durbin Witson di antara du dan 4-du dapat disimpulkan tidak terjadi autokorelasi.

\section{Hasil Uji Analisis Jalur (Path Analysis)}

Dasar perhitungan pengaruh antar variabel tersebut dapat disajikan pada tabel berikut:

Tabel 5

Hasil Perhitungan Pengaruh Langsung dan Tidak Langsung Antara Variabel Penelitian

\begin{tabular}{|c|c|c|c|}
\hline NO & Pengaruh Langsung & Pengaruh tidak Langsung & Total Pengaruh \\
\hline \multirow[t]{4}{*}{1} & Variabel $X_{1}$ & - & 0,001296 \\
\hline & $\mathrm{Y} \leftarrow \mathrm{X}_{1} \rightarrow \mathrm{Y}$ & & \\
\hline & & $\begin{array}{l}\text { Melalui } X_{2} Y \leftarrow X_{1} \Omega X_{2} \rightarrow Y \\
(-0,036)(0,251)(0,229)\end{array}$ & $-0,002069244$ \\
\hline & Total pengaruh $\mathrm{X}_{1} \rightarrow \mathrm{Y}$ & - & $-0,000773244$ \\
\hline \multirow[t]{7}{*}{2} & Variabel $\mathrm{X}_{2}$ & - & \\
\hline & $\mathrm{Y} \leftarrow \mathrm{X}_{2} \rightarrow \mathrm{Y}:\left(\rho \mathrm{yx}_{2}\right)^{2}=(0,229)^{2}$ & & 0,052441 \\
\hline & & $\begin{array}{l}\text { Melalui } \quad \mathrm{X}_{2} \mathrm{Y} \leftarrow \mathrm{X}_{1} \Omega \mathrm{X}_{2} \rightarrow \quad \mathrm{Y}(- \\
0,036)(0,223)(0,229)\end{array}$ & $-0,002069244$ \\
\hline & Total pengaruh $\mathrm{X}_{2} \rightarrow \mathrm{Y}$ & - & 0,050371756 \\
\hline & Total pengaruh $\mathrm{X}_{1}, \mathrm{X}_{2}$ & & 0,049598512 \\
\hline & Pengaruh Luar & & 0,950401488 \\
\hline & Jumlah & & 1,00 \\
\hline
\end{tabular}

Sumber: Data hasil output SPSS, 2018

Berdasarkan tabel dan diagram jalur tersebut di atas, menunjukkan bahwa total pengaruh perputaran modal kerja terhadap Return on Asset adalah sebesar - 0,000773244 atau $-0,08 \%$ dan total pengaruh Current Ratio terhadap Return on Asset sebesar 0,050371756 atau 5,04\%. Hubungan antar variabel independen yaitu perputaran modal kerja dan Current Ratio sebesar 0,223. Faktor residu atau faktor yang mempengaruhi Return on Asset selain perputaran modal kerja dan Current Ratio sebesar 0,950401488 atau $95 \%$. Secara simultan total pengaruh perputaran modal kerja dan Current Ratio terhadap Return on Asset adalah sebesar 0,05 artinya setiap perusahaan perputaran modal kerja dan Current Ratio akan menyebabkan perubahan Return on Asset sebesar 5\%. 


\section{Uji Signifikansi}

Untuk mengetahui tingkat signifikansi secara simultan pengaruh perputaran modal kerja dan Current Ratio terhadap Return on Asset dapat dijelaskan pada tabel berikut:

Tabel 6:

Anova

\begin{tabular}{llrrrrr} 
& \multicolumn{2}{c}{ ANOVA $^{\mathbf{a}}$} & & & \\
Model & & Sum of Squares & Df & Mean Square & F & Sig. \\
\hline 1 & Regression & 2,839 & 2 & 1,420 &, 183 &, $837^{\text {b }}$ \\
& Residual & 54,312 & 7 & 7,759 & & \\
& Total & 57,151 & 9 & & &
\end{tabular}

a. Dependent Variable: Return on Asset

b. Predictors: (Constant), Current Ratio, Perputaran Modal Kerja

\section{Sumber: Data hasil output SPSS, 2018}

Diketahui nilai $\mathrm{F}_{\text {hitung }}$ sebesar $0,183<\mathrm{F}_{\text {tabel }} 4,74$ maka artinya Ho diterima dan Ha ditolak, atau nilai signifikansi hitung $0,837>$ dari 0,05 dengan tingkat kesalahan $5 \%(\alpha 0,05)$. Jadi dapat disimpulkan tidak terdapat pengaruh signifikan perputaran modal kerja dan Current Ratio terhadap Return on Asset pada PT Mayora Indah Tbk periode 2007-2016.

\section{Koefisien Korelasi} berikut:

Berdasarkan hasil analisis dengan menggunakan program SPSS versi 22, hasilnya adalah sebagai

Tabel 7

Koefisien korelasi

\begin{tabular}{lrrrr} 
Model & R & R Square & Adjusted R Square & Std. Error of the Estimate \\
\hline 1 &, $223^{\mathrm{a}}$ &, 050 &,- 222 & 2,78547
\end{tabular}

a. Predictors: (Constant), Current Ratio, Perputaran Modal Kerja

b. Dependent Variable: Return on Asset

Sumber: Data hasil output SPSS, 2018

Artinya perputaran modal kerja, Current Ratio dengan Return on Asset pada PT Mayora Indah Tbk memiliki keeratan hubungan sebesar 0,233 , jika didasarkan pada penilaian tingkat koefisien korelasi menurut tabel di atas menunjukkan arti hubungan yang rendah, yang bisa diartikan sebagai perputaran modal kerja dan Current Ratio memiliki pengaruh yang tidak terlalu besar dan tidak terlalu kecil terhadap kondisi Return on Asset pada PT Mayora Indah Tbk. Hal ini bisa dibuktikan dengan jika terjadi kenaikan atau penurunan perputaran modal kerja dan Current Ratio maka tidak akan berpengaruh signifikan terhadap kondisi Return on Asset pada PT Mayora Indah Tbk.

\section{Persamaan Regresi}

Hasil penelitian pada analisis jalur (path analysis) dapat dilihat pada tabel di bawah ini:

\begin{tabular}{|c|c|c|c|c|c|}
\hline \multirow[b]{2}{*}{ Model } & \multicolumn{2}{|c|}{$\begin{array}{c}\text { Tabel } 8 \\
\text { Coefficients } \\
\text { Coefficients }^{\mathrm{a}} \\
\text { Unstandardized } \\
\text { Coefficients }\end{array}$} & \multirow{2}{*}{$\begin{array}{l}\text { Standardized } \\
\text { Coefficients } \\
\text { Beta }\end{array}$} & \multirow[b]{2}{*}{$\mathrm{T}$} & \multirow[b]{2}{*}{ Sig. } \\
\hline & B & Std. Error & & & \\
\hline (Constant) & 4,364 & 9,558 & & ,457 & ,662 \\
\hline Perputaran Modal Kerja &,- 277 & 2,965 &,- 036 &,- 093 & 928 \\
\hline Current Ratio & 2,148 & 3,568 & 229 & 602 &, 566 \\
\hline
\end{tabular}

a. Dependent Variable: Return on Asset

Sumber: Data hasil output SPSS, 2018 
Berdasarkan hasil perhitungan pada tabel coefficients dapat menghasilkan bentuk persamaan regresi sebagai berikut $\mathrm{Y}=4,364-0,277 \mathrm{X}_{1}+2,148 \mathrm{X}_{2}$. Dari persamaan tersebut dapat dijelaskan sebagai berikut:

1. Konstanta, sebesar 4,364 menyatakan bahwa jika perputaran modal kerja dan Current Ratio sebesar nol, maka Return on Asset PT Mayora Indah Tbk sebesar 4,364 kali.

2. Koefisien korelasi $X_{1}$ perputaran modal kerja sebesar -0,277 menyatakan bahwa setiap kenaikan perputaran modal kerja sebesar 1 kali akan menurunkan Return on Asset sebesar 0,277 kali atau setiap kenaikan perputaran modal kerja maka Return on Asset PT Mayora Indah Tbk akan turun.

3. Koefisien korelasi $\mathrm{X}_{2}$ Current Ratio sebesar 2,148 kali menyatakan bahwa setiap kenaikan Current Ratio sebesar 1 kali akan menaikan Return on Asset sebesar 2,148 kali atau setiap kenaikan Current Ratio maka Return on Asset PT Mayora Indah Tbk akan naik.

\section{Pengaruh Perputaran Modal Kerja terhadap Return on Asset pada PT Mayora Indah Tbk Periode 2007-2016}

Untuk mengetahui besarnya pengaruh parsial antara variabel bebas dengan variabel terikat dilakukan dengan menggunakan analisis jalur (path analysis). Dari hasil pengolahan data dengan menggunakan formula, hasilnya adalah sebagai berikut:

Tabel 9

Besar Pengaruh Perputaran Modal Kerja Terhadap Return On Asset

\begin{tabular}{|c|c|c|c|}
\hline NO & Pengaruh Langsung & Pengaruh tidak Langsung & Total Pengaruh \\
\hline \multirow[t]{4}{*}{1} & Variabel $\mathrm{X}_{1}$ & - & 0,001296 \\
\hline & $\mathrm{Y} \leftarrow \mathrm{X}_{1} \rightarrow \mathrm{Y}$ & & \\
\hline & & $\begin{array}{l}\text { Melalui } X_{2} Y \leftarrow X_{1} \Omega X_{2} \rightarrow Y \\
(-0,036)(0,251)(0,229)\end{array}$ & $-0,002069244$ \\
\hline & Total pengaruh $\mathrm{X}_{1} \rightarrow \mathrm{Y}$ & - & $-0,000773244$ \\
\hline
\end{tabular}

Sumber: Data hasil output SPSS, 2018

Berdasarkan tabel di atas, besarnya pengaruh perputaran modal kerja terhadap Return on Asset secara langsung adalah 0,001296 , sedangkan pengaruh tidak langsung atau besarnya pengaruh perputaran modal kerja terhadap Return on Asset melalui Current Ratio adalah -0,002069244, sehingga total keseluruhan adalah $-0,000773244$, artinya bahwa perputaran modal kerja berpengaruh negatif terhadap Return on Asset sebesar -0,08\%.

Untuk mengetahui tingkat signifikansi secara parsial pengaruh Perputaran Modal Kerja terhadap Return on Asset dapat dijelaskan pada tabel berikut ini:

Tabel 10

Uji Hipotesis Perputaran Modal Kerja Terhadap Return On Asset

\begin{tabular}{|c|c|c|c|c|c|}
\hline \multirow[b]{2}{*}{ Model } & \multicolumn{2}{|c|}{$\begin{array}{l}\text { Coefficients }^{\mathbf{a}} \\
\text { Unstandardized } \\
\text { Coefficients }\end{array}$} & \multirow{2}{*}{$\begin{array}{c}\begin{array}{c}\text { Standardized } \\
\text { Coefficients }\end{array} \\
\text { Beta }\end{array}$} & \multirow[b]{2}{*}{$\mathrm{T}$} & \multirow[b]{2}{*}{ Sig. } \\
\hline & $\mathrm{B}$ & Std. Error & & & \\
\hline (Constant) & 4,364 & 9,558 & & ,457 & ,662 \\
\hline Perputaran Modal Kerja &,- 277 & 2,965 &,- 036 &,- 093 & ,928 \\
\hline Current Ratio & 2,148 & 3,568 & 229 &, 602 & 566 \\
\hline
\end{tabular}

a. Dependent Variable: Return on Asset

Sumber: Data hasil output SPSS, 2018

Hasil perhitungan uji parsial pada tabel coefficients diperoleh tingkat signifikansi sebesar 0,928 dengan tingkat kesalahan sebesar $5 \%(\alpha, 0,05)$ sehingga signifikansi $>\alpha$ atau $0,928>0,05$ atau nilai thitung 
$-0,093<\mathrm{t}_{\text {tabel }} 2,306$ artinya Ho diterima dan Ha ditolak, artinya secara parsial "Tidak terdapat pengaruh signifikan perputaran modal kerja terhadap Return on Asset PT Mayora Indah Tbk."

Pengaruh Current Ratio terhadap Return on Asset pada PT Mayora Indah Tbk Periode 2007-2016

Untuk mengetahui besarnya pengaruh parsial antara variabel bebas dengan variabel terikat dilakukan dengan menggunakan analisis jalur (path analysis). Dari hasil pengolahan data dengan menggunakan formula, hasilnya adalah sebagai berikut:

Tabel 11:

Besar Pengaruh Current Ratio Terhadap Return On Asset

2 Variabel $\mathrm{X}_{2}$
$\mathrm{Y} \leftarrow \mathrm{X}_{2} \rightarrow \mathrm{Y}:\left(\rho \mathrm{yx}_{2}\right)^{2}=(0,22$
$9)^{2}$

\begin{tabular}{clc}
\hline & Melalui $\mathrm{X}_{2} \mathrm{Y} \leftarrow \mathrm{X}_{1} \Omega \mathrm{X}_{2} \rightarrow \mathrm{Y}(-$ & $-0,002069244$ \\
& $0,036)(0,251)(0,229)$ & \\
\hline Total pengaruh $\mathrm{X}_{2} \rightarrow \mathrm{Y}$ & - & 0,050371756
\end{tabular}

Sumber: Data hasil output SPSS, 2018

Berdasarkan tabel di atas, besarnya pengaruh Current Ratio terhadap Return on Asset secara langsung adalah 0,052441, sedangkan pengaruh tidak langsung atau besarnya pengaruh Current Ratio terhadap Return on Asset melalui perputaran modal kerja adalah -0,002069244, sehingga total keseluruhan adalah 0,050371756, artinya bahwa Current Ratio berpengaruh terhadap Return on Asset sebesar $5,04 \%$.

Tabel 12

Uji Hipotesis Current Ratio Terhadap Return On Asset

Coefficients $^{\mathrm{a}}$

\begin{tabular}{lrrrrr}
\hline & \multicolumn{5}{c}{ Standardized } \\
Model & Unstandardized Coefficients & Coefficients & & \\
(Constant) & B & Std. Error & Beta & \multicolumn{1}{c}{ T } & \multicolumn{1}{c}{ Sig. } \\
Perputaran Modal Kerja & 4,364 & 9,558 & &, 457 &, 662 \\
Current Ratio &,- 277 & 2,965 &,- 036 &,- 093 &, 928 \\
& 2,148 & 3,568 &, 229 &, 602 &, 566
\end{tabular}

a. Dependent Variable: Return on Asset

Sumber: Data hasil output SPSS, 2018

Hasil perhitungan uji parsial pada tabel coefficients diperoleh tingkat signifikansi sebesar 0,566 dengan tingkat kesalahan sebesar $5 \%(\alpha 0,05)$ sehingga signifikansi $>\alpha$ atau 0,566 $>0,05$ atau nilai $t_{\text {hitung }} 0,602<\mathrm{t}_{\text {tabel }} 2,306$ artinya Ho diterima dan $\mathrm{Ha}$ ditolak, artinya secara parsial "Tidak terdapat pengaruh signifikan Current Ratio terhadap Return on Asset PT Mayora Indah Tbk."

\section{KESIMPULAN}

Berdasarkan hasil analisis pada laporan keuangan PT Mayora Indah Tbk periode 20072016 bahwa perputaran modal kerja, Current Ratio, dan Return on Asset mengalami fluktuatif. Pengaruh perputaran modal kerja dan Current
Ratio terhadap Return on Asset sebesar 5\%, pengaruh perputaran modal kerja terhadap Return on Asset sebesar -0,08\%, dan pengaruh Current Ratio terhadap Return on Asset sebesar 5,04\%. Berdasarkan uji hipotesis hasilnya adalah tidak terdapat pengaruh signifikan perputaran modal kerja, Current Ratio terhadap Return on Asset pada PT Mayora Indah Tbk periode 20072016 baik secara parsial ataupun secara simultan.

\section{DAFTAR PUSTAKA}

Kasmir. (2015). Analisis Laporan Keuangan. Jakarta: Rajawali Pers. 
Somantri, A., \& Muhidin, S. A. (2006). Aplikasi Statistika dalam Penelitian. Bandung: CV. Pustaka Setia. 